\title{
Simulation of Boost Type DC-DC Converter for Photovoltaic Systems
}

\author{
Fotovoltaik Sistemler için Yükseltici Tip DA-DA Dönüştürücünün Benzetimi
}

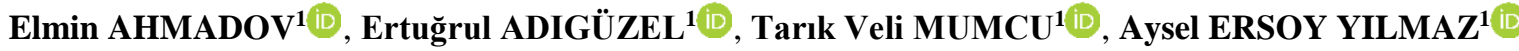 \\ ${ }^{l}$ Department of Electrical and Electronics Engineering, İstanbul University.- Cerrahpașa, İstanbul, Turkey
}

\begin{abstract}
Today, the use of renewable energy sources is increasing. Photovoltaic systems are also among the renewable energy sources. These systems are a direct current source and cannot produce energy when there is no sunlight. In this study, performance analysis of the Hard Switching (HS) DC-DC boost converter and Soft Switching (SS) DC-DC boost converter in the literature with PID controller were performed on the photovoltaic system. The performance of the converters, which were simulated in Matlab/Simulink software was 18 and $24 \mathrm{~V}$ output voltage for 12-13 V input voltage. According to the results obtained from the study, the most successful results for a photovoltaic system with PID controller produced Hard Switching DC-DC boost converter.
\end{abstract}

Keywords: DC/DC Converter, Hard Switching, Soft Switching, PID Controller

\section{Öz}

Günümüzde yenilenebilir enerji kaynaklarının kullanımı giderek artmaktadır. Fotovoltaik sistemler de yenilenebilir enerji kaynakları arasında bulunmaktadır. Bu sistemler bir doğru akım kaynağı olup güneş 1şı̆̆ııın olmadığ zamanlarda enerji üretememektedir. Bu çalışmada literatürde yer alan Sert Anahtarlamalı DA-DA yükseltici konvertör ile Yumuşak Anahtarlamalı DA-DA yükseltici konvertörün fotovoltaik sistem üzerinde PID kontrolörle performans analizi yapılmıştır. Matlab/Simulink yazılımında benzetimi gerçekleştirilen konvertörlerin 12-13 V giriş gerilimine karşılık 18 ve $24 \mathrm{~V}$ çıkış gerilimindeki performansları izlenmiştir. Çalışmadan elde edilen sonuçlara göre PID kontrolörlü fotovoltaik bir sistem için en başarılı sonuçları Sert Anahtarlamalı DA-DA yükseltici konvertör üretmiştir.

Anahtar Kelimeler: DA/DA Dönüştürücü, Sert Anahtarlama, Yumuşak Anahtarlama, PID Kontrolör

\section{INTRODUCTION}

Solar cells in photovoltaic (PV) systems are an accurate source of current and different current-voltage values can be obtained by connecting these batteries serially or parallel. When converters are evaluated within the scope of power electronics, it is still seen that many researchers are among the research subjects [1]. With power electronics factors such as the desired amplitude, shape and frequency, etc. can be presented from energy sources to the user or other units. One of the converters is DC-DC converters in order to meet the need in these areas. DC-DC converters convert the current correct voltage to lower or higher values. DC-DC converters with high switching frequencies with ease of control, high power density and rapid response time are widely used in industrial applications. This situation allows the dimensions of circuit elements such as capacitors, coils and transformers used in converter circuits to be preferred as small. On the other hand, increasing switching frequency increases switching losses and electromagnetic interference (EMI) value [2].

Switching losses occurring in the converter are caused by the decrease in the voltage at the ends of the semiconductor element and the rise of the current passing through the semiconductor during transmission of the semiconductor element in the circuit. During transmission, the loss of energy in the parasitic capacitor discharge and the loss of energy that occurs during the reverse polarization process of the diode also occur as a loss of switching [3]. For this reason, converter circuits use Soft Switching (SS) instead of Hard Switching (HS). With the help of circuits expressed as suppression cells in SS, the switching frequency can be increased by reducing the losses that occur during switching [4].

Hua et al. (1994a) in their study, $1 \mathrm{~kW}$ power and $100 \mathrm{kHz}$ frequency running converter designed with the active suppression cell the performance of the boost converter was able to increase from $93 \%$ to $97 \%$ as the base switcher went to cut together with the basic switch. [5]. 
Hua et al. (1994b) in their study, the basic key was transmitted with soft switching in this converter which can operate at a frequency of $600 \mathrm{~W}$ power and 300 $\mathrm{kHz}$ and performance of up to $98 \%$ from the converter were achieved [6].

Bodur and Bakan (2002) in their study, many problems were fixed using the active suppression cell model they designed to address some basic problems that occur in the source [6] and the performance of the converter increased from $91 \%$ to $97 \%$ [7].

In 2007, Das and Moschopoulos's research showed that it is the most efficient circuit that can be used in high-power applications than all other active suppression cell circuits examined [8].

Kofinas et al. in 2015, developed an expert Maximum Power Point Monitor (MPPT) model based directly on the basis of the artificial neural networks algorithm in partially overshadowed systems. In this study, it consists of a lowering converter and a load connected parallel to the PV source. Performance of the designed system's algorithm has been shown to produce better results than conventional algorithms with a changeeye [9], [10].

It is seen that many types of controllers are used in the literature for the boost DC-DC converter inspection. By constantly checking the margin of error between the actual output voltage and the converter reference, the controller corrects the converter's operating error to form the parameters of the expected system response. The closed cycle controller structure which uses traditional types of PID and PI controllers, is frequently used under the supervision of boost converters [11], [12], [13].

\section{MATERIALS AND METHODS}

In this study, two different DC-DC boost converter models were used to raise a PV system output voltage. When designing the system, the output voltage of the PV model is set to $12-13 \mathrm{~V}$. This value was applied to the converter input and two different voltage values (18 and $24 \mathrm{~V}$ ) were obtained from the converter output. In obtaining these voltage values, the determination of the switching signal was carried out by the PID controller. We use different frequencies to get two voltages on the exit. We use it in the system because the frequencies are the PID control that provides us with. The material and method used in the system are described in detail below.

\subsection{Simulation of Photovoltaic System}

The PV system simulation was theoretically calculated at the desired value ranges. Thus, it is modeled so that it can be integrated into all systems used in the industry. It is designed to obtain $12 \mathrm{~V}$ from the output of the system. The system's Matlab/Simulation diagram is shown in Figure 1.

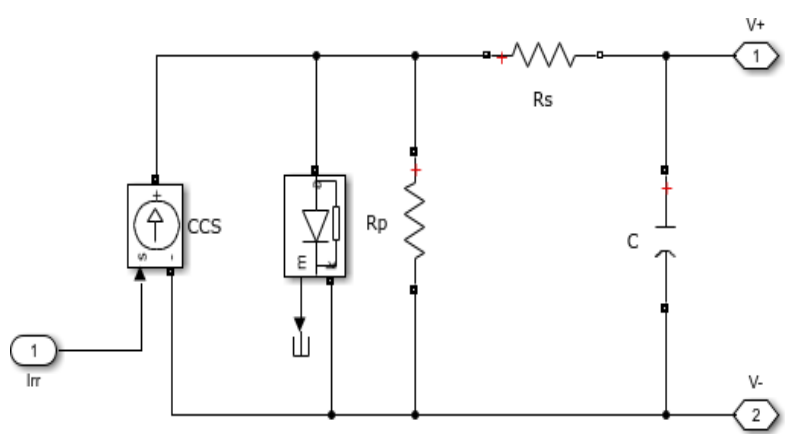

Figure 1. PV system simulation scheme.

The $\mathrm{Rp}, \mathrm{Rs}$ and $\mathrm{C}$ values used in PV system simulation are $100 \Omega, 0.1 \Omega$ and $10 \mathrm{mF}$, respectively. In addition, two different references were taken in solar radiation value when modeling the PV system. The change in the value of sunlight within 5 seconds occurs in 1.5 and 3.5 seconds in Figure 2.

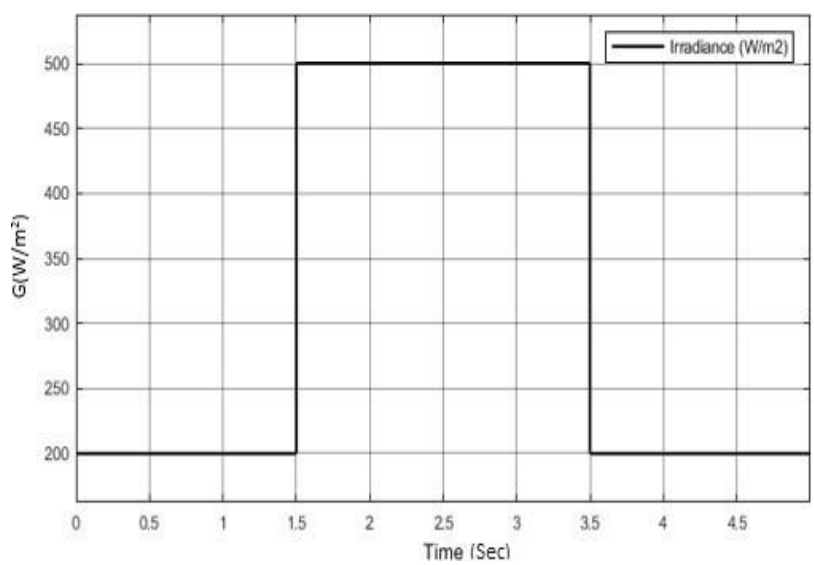

Figure 2. Solar radiation (Irradiance) exchange.

\subsection{PID Simulation}

Proportional-Integral-Derivative (PID) control, which is among traditional control methods, is a control system that combines the advantages of Proportional, Integral and Derivative control in a single system. PID control is now a widely used control method.PID is a widely used control system. It is a feedback system by calculating the difference between the output value and the desired value. There are actually block models in Matlab, but no model could meet the needs of this system. So this system is created especially for this work. $\mathrm{P}$ proportional and integral derivative coefficients obtained with a coefficient of 0.01-2.5-0, we made our output signal compatible with the PID control. PID control circuit is designed to provide the switching signal required for the voltage value to be obtained from the converter output. The simulation scheme for the commission is given in Figure 3. By applying the difference (error) of the Vref and Vout voltages to the PID input, the switching signal is determined to obtain the desired voltage from the converter output. Vref is determined as 18 and $24 \mathrm{~V}$. Thus, the voltage applied to the converter input (PV system output: $12-13 \mathrm{~V}$ ) is obtained as 18 and $24 \mathrm{~V}$ at the converter output. 


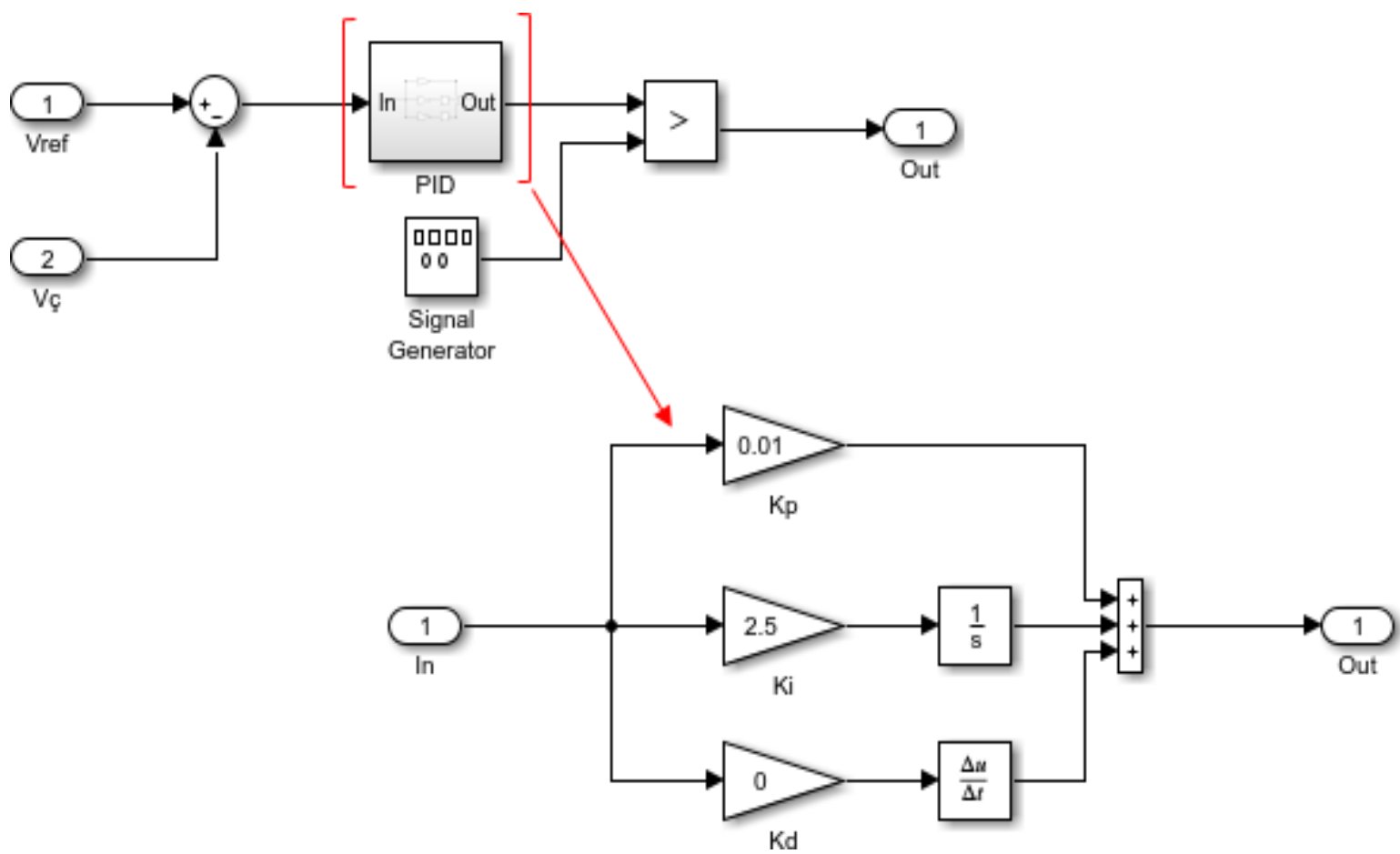

Figure 3. PID control simulation scheme

\subsection{Simulation of DC-DC Converters}

The voltage value obtained from the PV system output has been raised in two different converter models with hard and soft switching.

\subsubsection{DC-DC converter simulation with hard switching}

This converter is the traditional model used in industrial applications. The model's simulation diagram is shown in Figure 4.

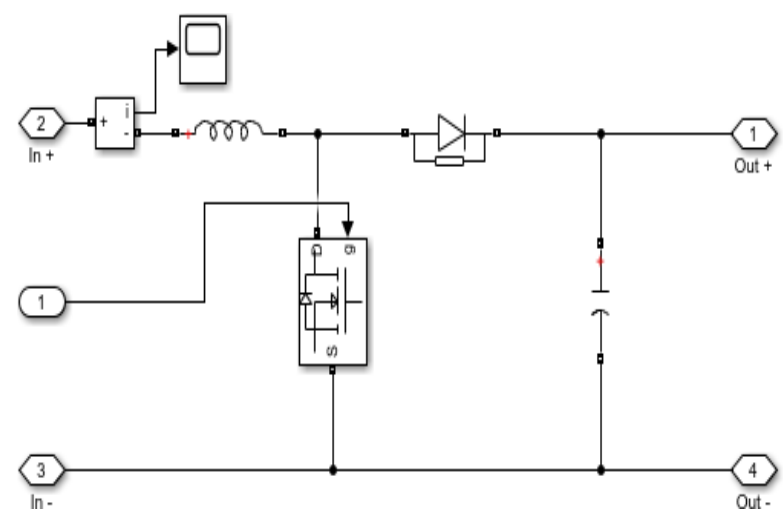

Figure 4. DC-DC converter simulation with HS

This traditional model uses MOSFET for switching; Inductance, Capacitance and Diode values were also determined as $0.3 \mathrm{mH}, 250 \mathrm{uF}$ and $0.8 \mathrm{~V}$ respectively.
2.2.1 DC-DC converter simulation with soft switching

The same parameter values were used to perform a comparative analysis of both models. This model is thought to be a soft switching insulated circuit and transformer was used in the part of the converter after MOSFET. The simulation diagram of this model is given in Figure 5.

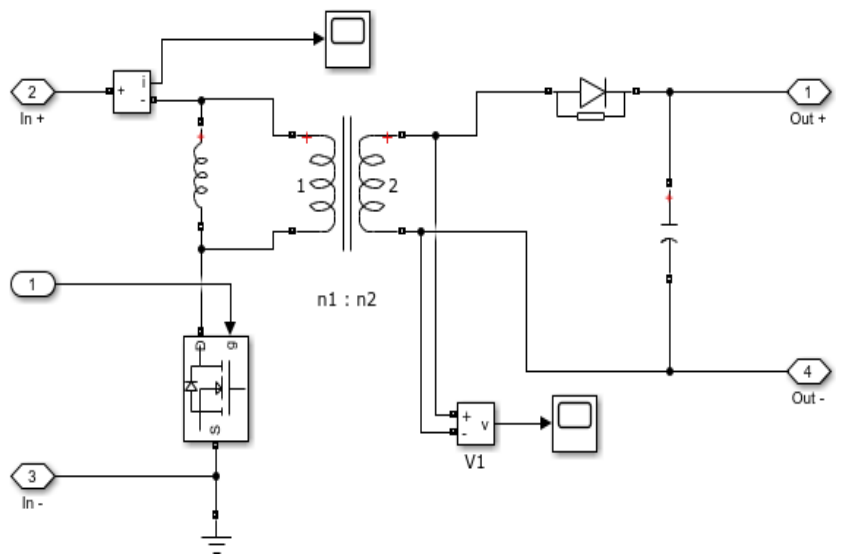

Figure 5. DC-DC converter simulation with SS The block diagram of both designed models are presented in Figure 6. 


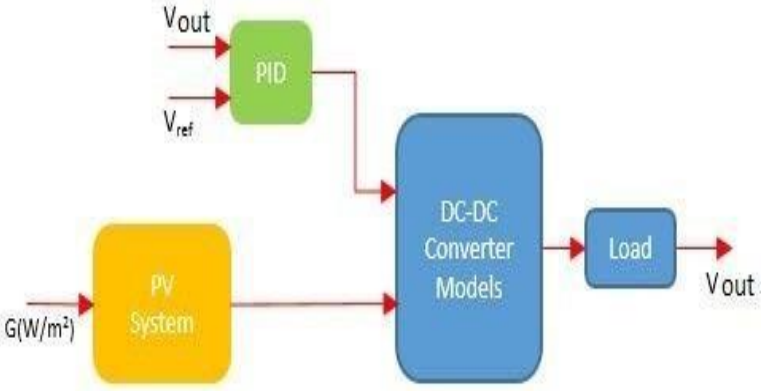

Figure 6. Block model of the system.

\section{RESULTS AND DISCUSSION}

The performance of both models for $18 \mathrm{~V}$ is shown in Figure 19. When Figure 19 is examined, it is seen that the hard switching converter for $18 \mathrm{~V}$ gives better answers to the change in solar radiation values with PID controller in the aforementioned PV system. The performance of both models for $24 \mathrm{~V}$ is shown in Figure 20. When figure 20 is examined, it is seen that the hard switching converter for $24 \mathrm{~V}$ gives better answers to the change in solar radiation values with
PID controller in the aforementioned PV system."

DC-DC converters with HS and SS respectively;

- $\quad$ Converter output $18 \mathrm{~V}$ and load fixed

- $\quad$ Converter output $24 \mathrm{~V}$ and load fixed

- Converter output voltage variable and load constant

- $\quad$ Converter output voltage variable and load increased by $100 \%$

- Converter output voltage variable and load reduced by $50 \%$ results have been obtained in five different categories.

3.1. DC-DC converter results with hard switching The graph obtained in case the desired voltage is $18 \mathrm{~V}$ and the load is constant is shown in Figure 7.

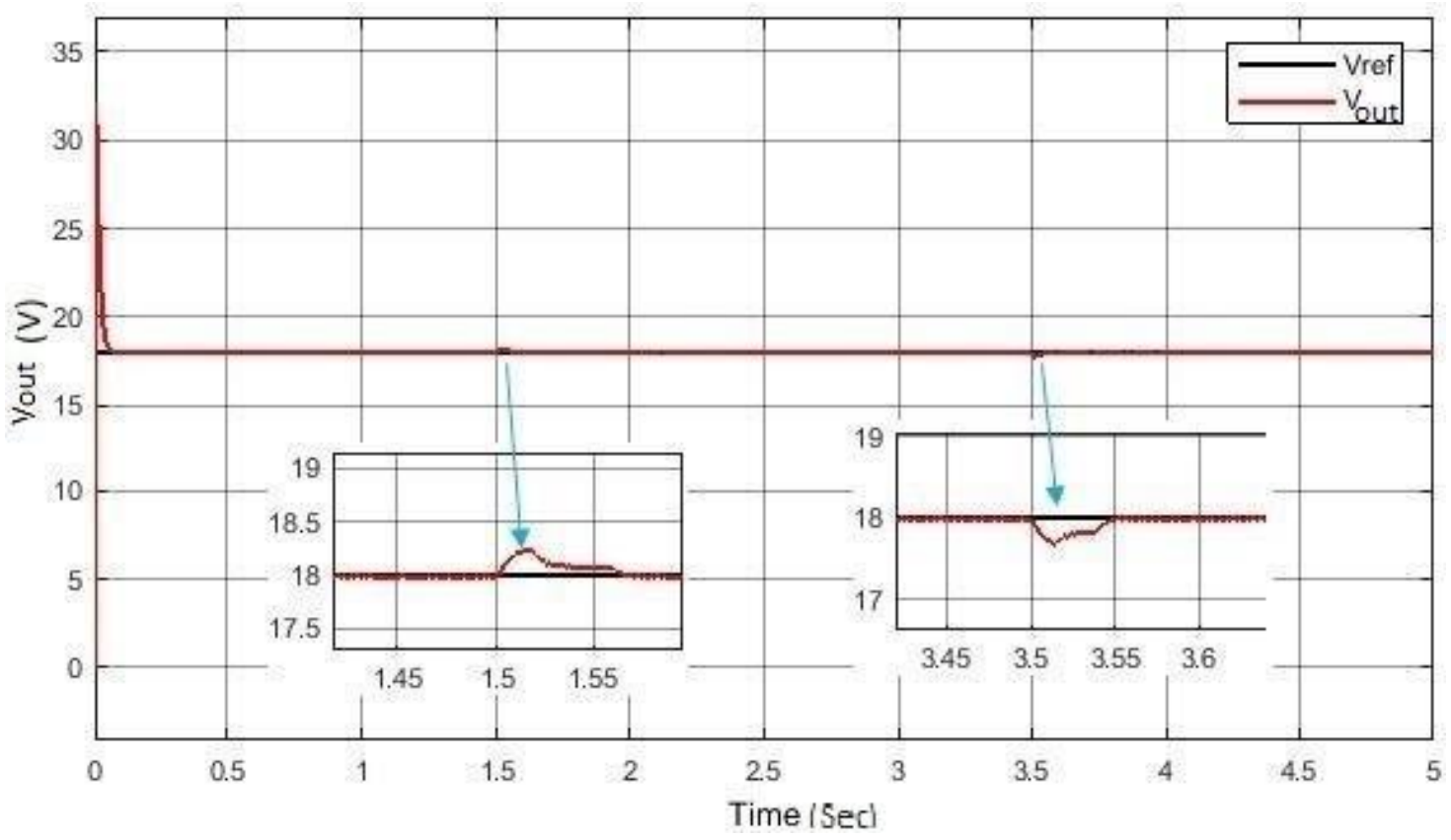

Figure 7. The graph obtained when the output voltage is asked to be $18 \mathrm{~V}$

When obtaining this graph, the solar radiation change of the PV system varies as given in Figure 2. In addition, the load change is fixed. Converter output voltage values varied in the range of 17.98 to $18.01 \mathrm{~V}$. When Figure 7 is examined, it is seen that there is a short-term instability in the output voltage value in 1.5 and 3.5 seconds. With PID controller the output voltage is kept at the desired level by providing the necessary switching in a very short period of time. The controller makes approximately $\pm 0.12 \%$ error in the output voltage value. The desired voltage at the converter output is $24 \mathrm{~V}$ and the resulting graph is shown in Figure 8 if the load is fixed. 


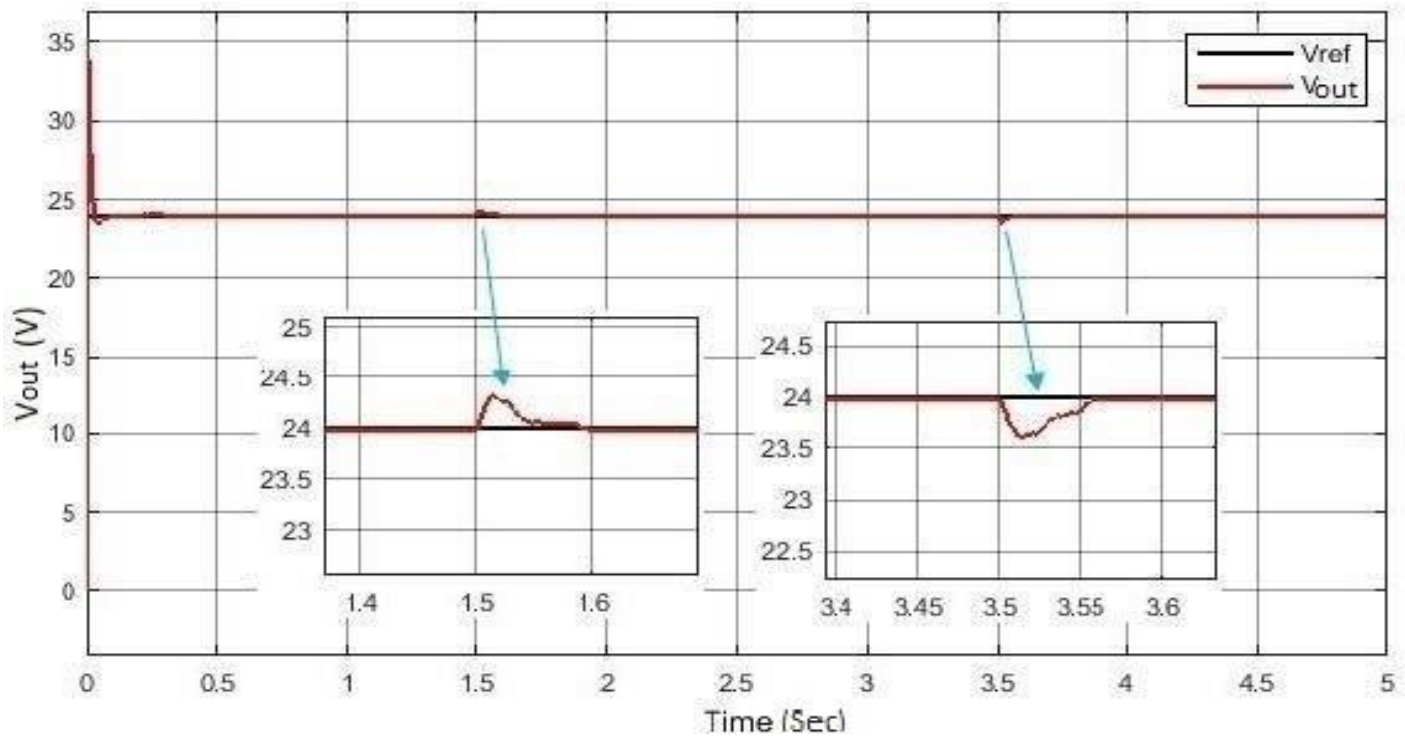

Figure 8. The graph obtained when prompted to have output voltage $24 \mathrm{~V}$

When obtaining this graph, the solar radiation change of the PV system varies as given in Figure 2 . In addition, the load change is fixed. Converter output voltage values vary in $\mathrm{v}=23.99$ to $24.02 \mathrm{~V}$ range. When Figure 8 is examined, it is observed that there is a short-term imbalance in the output voltage value of 1.5 and 3.5 seconds. With a PID controller the output voltage is kept at the desired level by providing the necessary switching in a very short period of time. The controller makes approximately $\pm 0.08 \%$ error in output voltage value.

In this study, the output voltage value was changed from $18 \mathrm{~V}$ to $24 \mathrm{~V}$ and from $24 \mathrm{~V}$ to $18 \mathrm{~V}$ and the results were given in Figure 9 and 10 respectively.

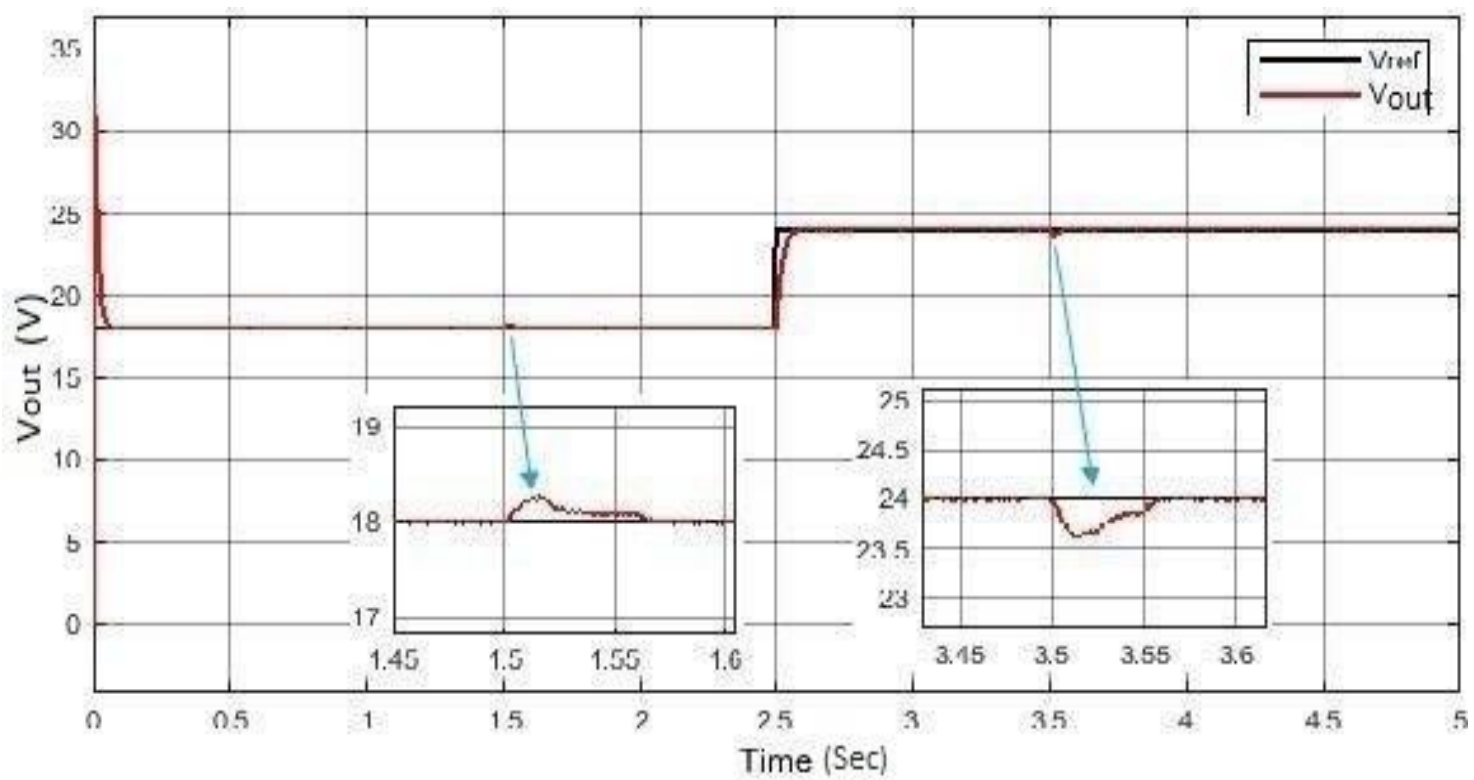

Figure 9. The graph obtained when output voltage rises from $18 \mathrm{~V}$ to $24 \mathrm{~V}$ 


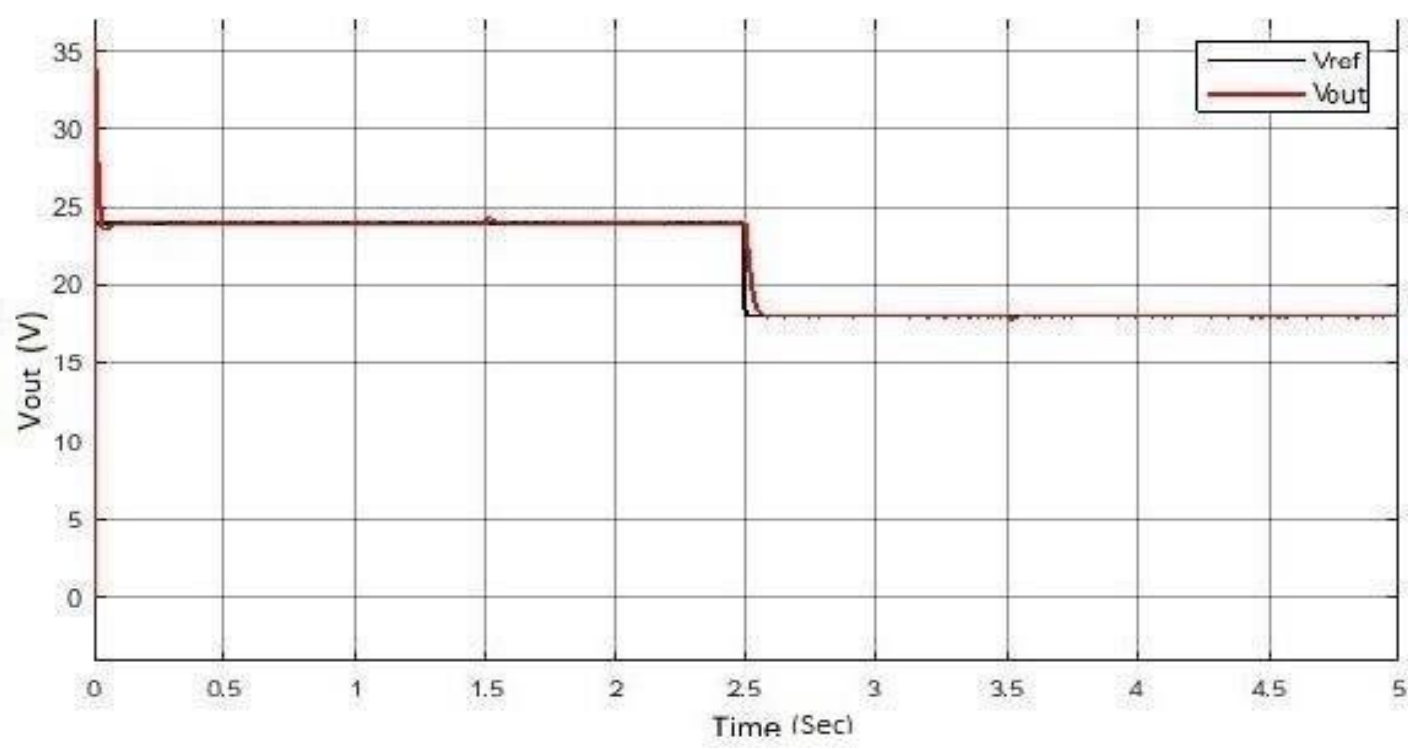

Figure 10. The graph obtained when output voltage drops from $24 \mathrm{~V}$ to $18 \mathrm{~V}$

In this work, which is fixed with load change, the converter for $18 \mathrm{~V}$ output voltage produced voltage in the range of $17.98-18.01 \mathrm{~V}, 24 \mathrm{~V}$ to 23.99 to 24.02 $\mathrm{V}$. The converter output voltage value was increased from $18 \mathrm{~V}$ to $24 \mathrm{~V}$ while the load increased by $100 \%$ and system performance was examined. The results are shown in Figure 11.
When the load is increased by $100 \%$ a stable output is achieved when the converter output value is $18 \mathrm{~V}$ while when the converter output is $24 \mathrm{~V}$ there is a negligent level of instability. The converter output voltage value was increased from $18 \mathrm{~V}$ to $24 \mathrm{~V}$ while the load was reduced by $50 \%$ and system performance was examined. The results are shown in Figure 12.

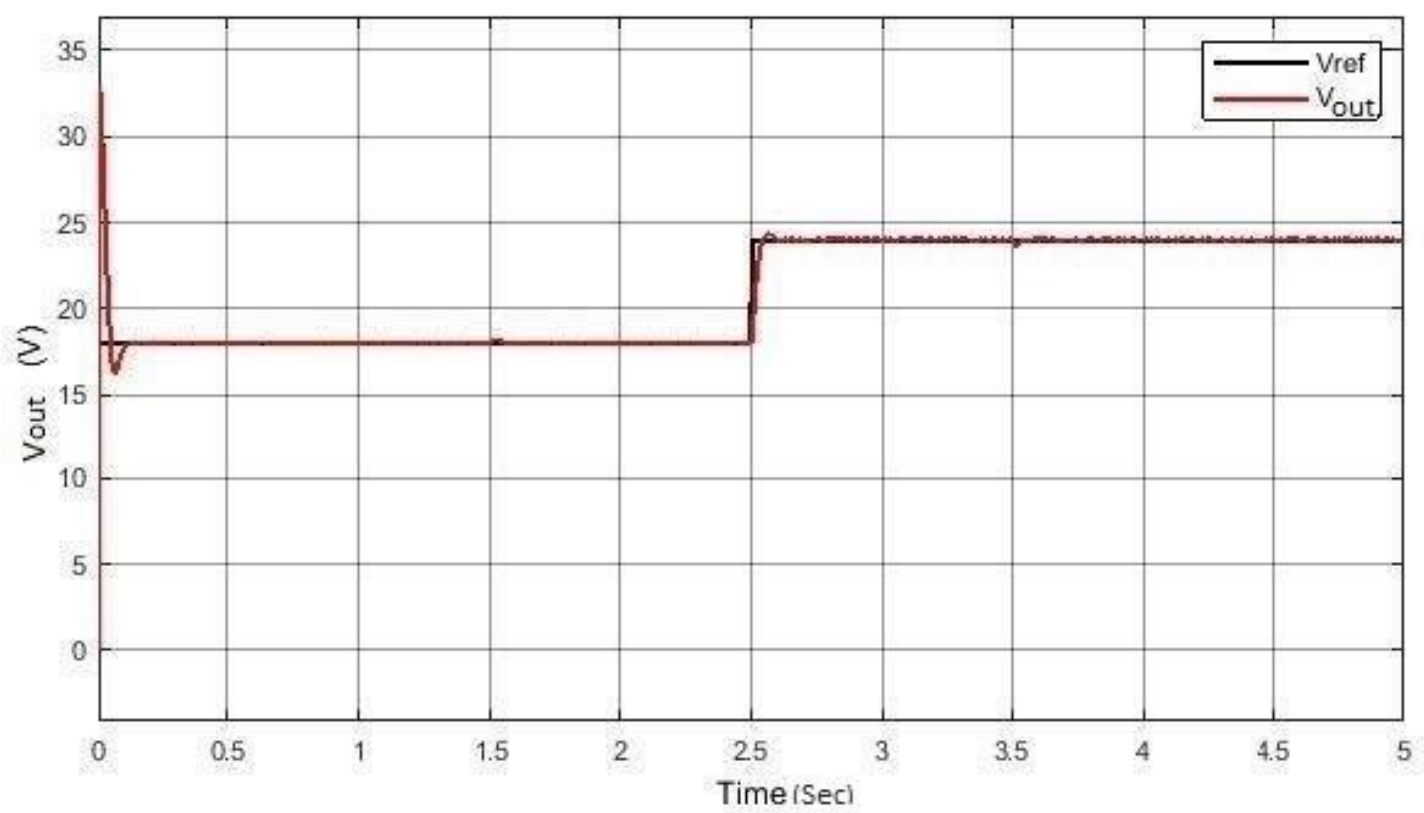

Figure 11. Results when the load is increased by $100 \%$ 


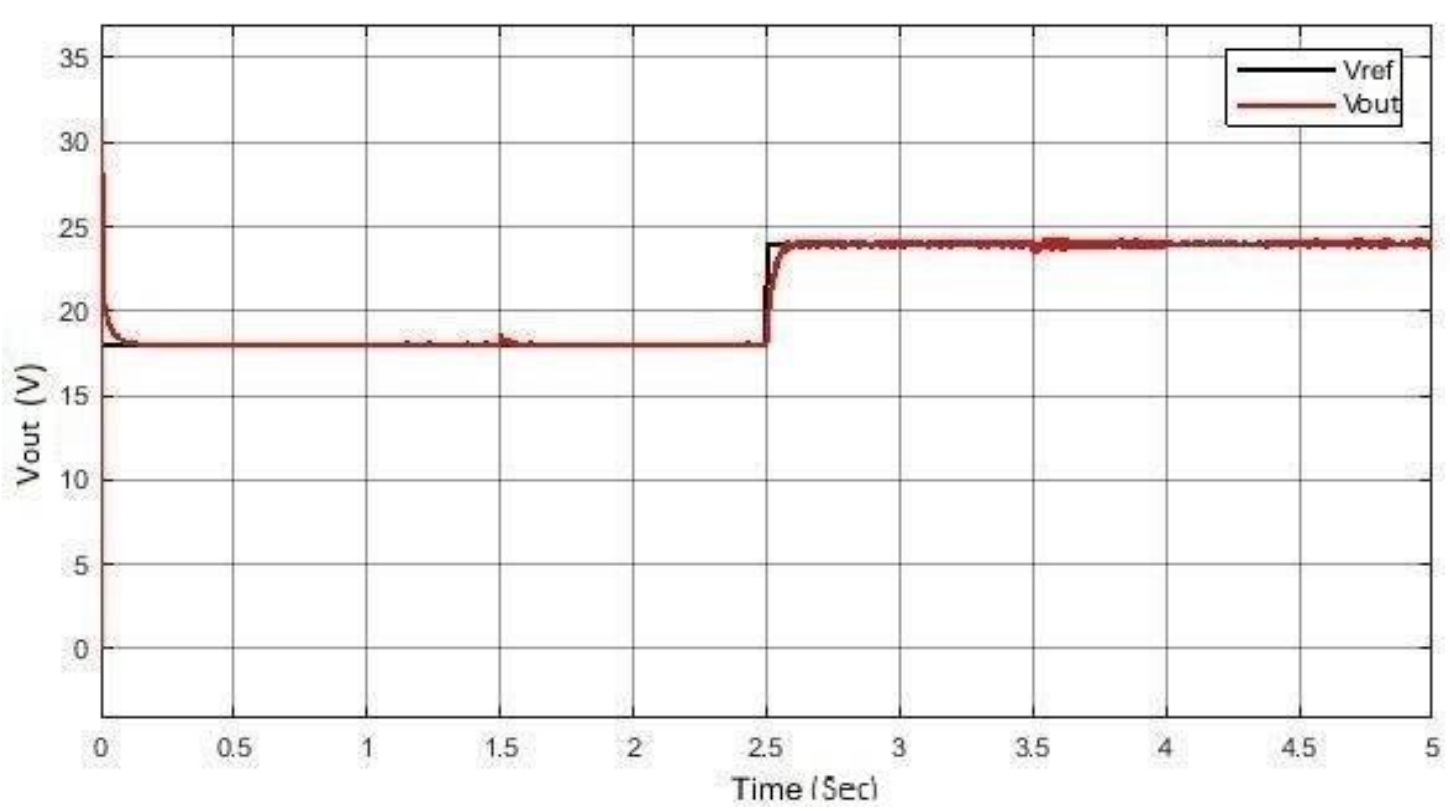

Figure 12. Results obtained when the load is reduced by $50 \%$.

When Figure 12 is examined, it is seen that if the load is reduced by $50 \%$ the converter output produces the expected voltage value for $18 \mathrm{~V}$. However, it is observed that the instability of the output voltage value for $24 \mathrm{~V}$ increases and even when time shows 3.5 the sun's radiation value changes and instability increases.
3.2. DC-DC converter results with soft switching If the desired voltage at the converter output is $18 \mathrm{~V}$ and the load is constant, the resulting graph is shown in Figure 13. When obtaining this graph the solar radiation change of the PV system varies as given in Figure 2. Converter output voltage values varied in the range of 17.95 to $18.03 \mathrm{~V}$.

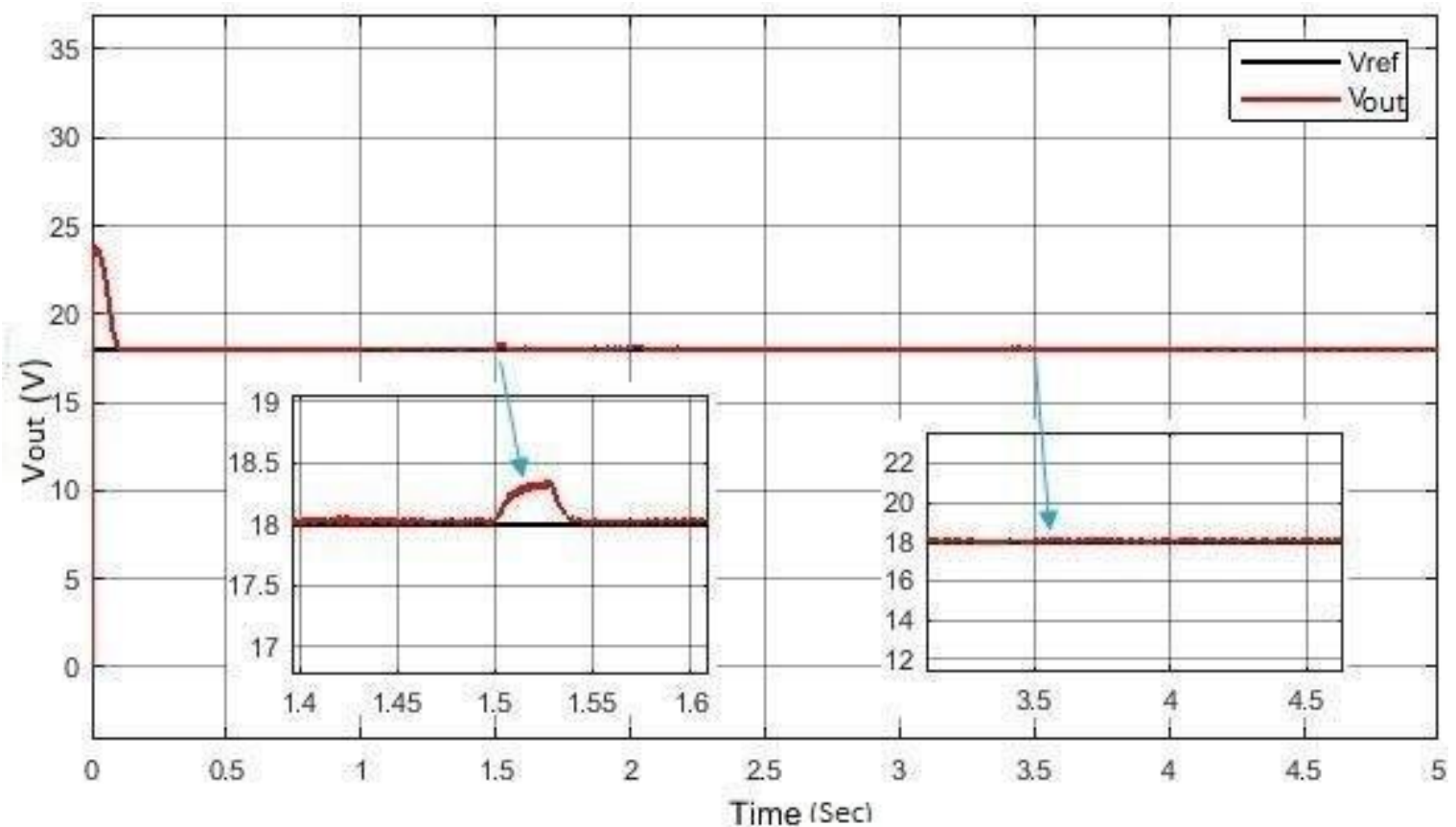

Figure 13. Results obtained when the output voltage is asked to be $18 \mathrm{~V}$.

When Figure 13 is examined, it is seen that there is a short-term instability in the output voltage value in 1.5 and 3.5 seconds. With PID controller the output voltage is kept at the desired level by providing the necessary switching in a very short period of time. The controller makes approximately $\pm 0.28 \%$ error in the output voltage value. The graph obtained in case the desired voltage at the converter output is $24 \mathrm{~V}$ is shown in Figure 14. When obtaining this graph, the solar radiation change of the PV system varies as given in Figure 2. In addition, the load change is fixed. Converter output voltage values varied in the range of 23.50 to $24.50 \mathrm{~V}$. 


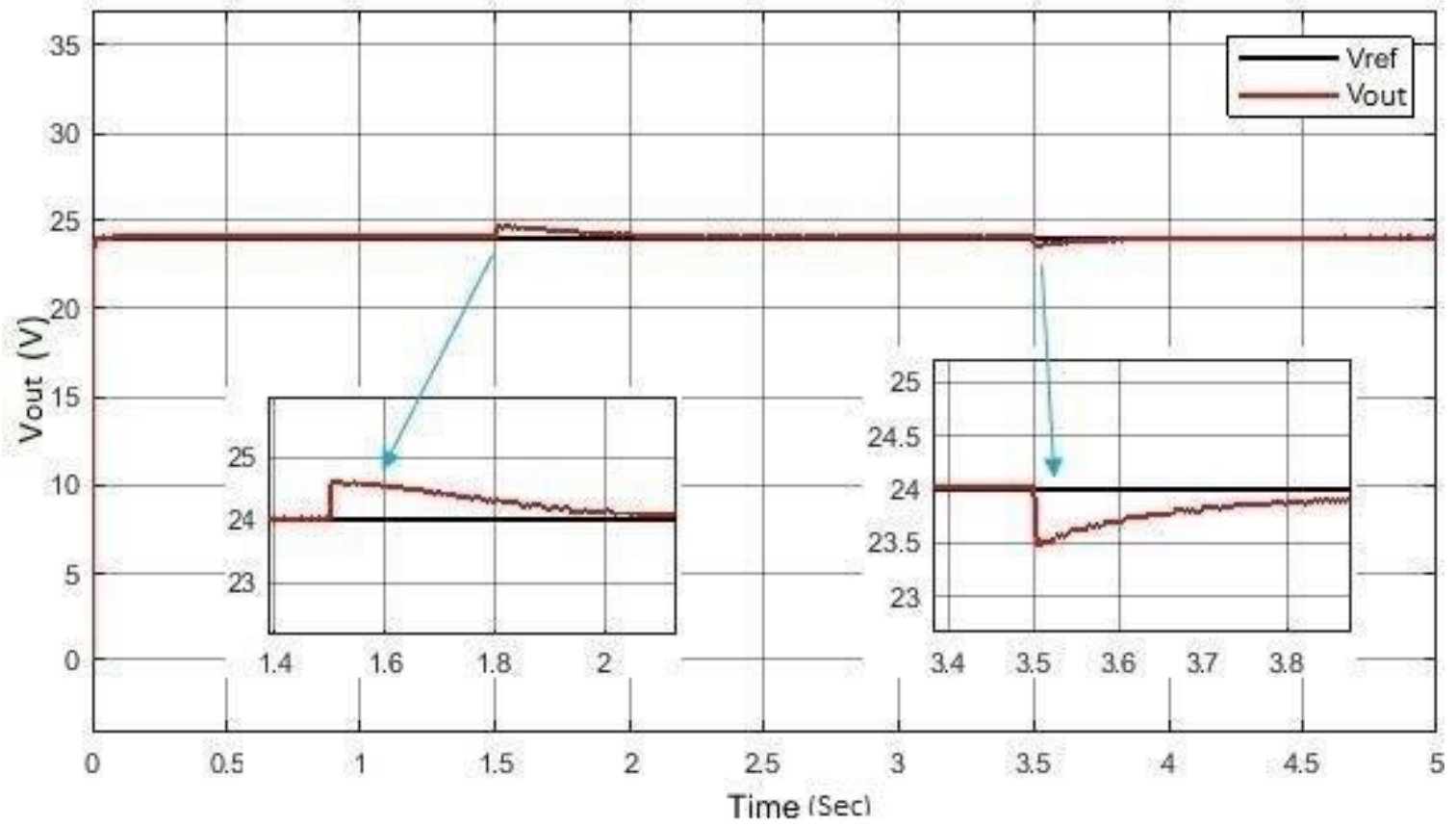

Figure 14. Results obtained when the output voltage is requested to be $24 \mathrm{~V}$.

Although the converter output voltage is at the desired level, it is observed that the level of instability increased during the change in the amount of solar radiation and thus it is incorrect in the converter output voltage.

When the Figure is examined in 14 , it is seen that there is a short-term instability in the output voltage value in 1.5 and 3.5 seconds. With PID controller the output voltage is kept at the desired level by providing the necessary switching in a very short period of time. The controller makes approximately $\pm 2.2 \%$ error in the output voltage value.
The converter output voltage value has been changed from $18 \mathrm{~V}$ to $24 \mathrm{~V}$ and from $24 \mathrm{~V}$ to $18 \mathrm{~V}$ and the results are given in Figure 15 and 16 respectively. Here, depending on the amount of solar radiation converter output voltage values are seen. When the Figure is examined 15 , it is seen that the error was made albeit for a short period of time during the change of the sun's radiation value for $18 \mathrm{~V}$ but the desired voltage value was obtained in a short time with the PID controller. On the other hand, it is observed that there is a system error during the decrease of the solar radiation value for $24 \mathrm{~V}$ and the output voltage of the converter catches in approximately one second. A Similar change is seen in Figure 16.

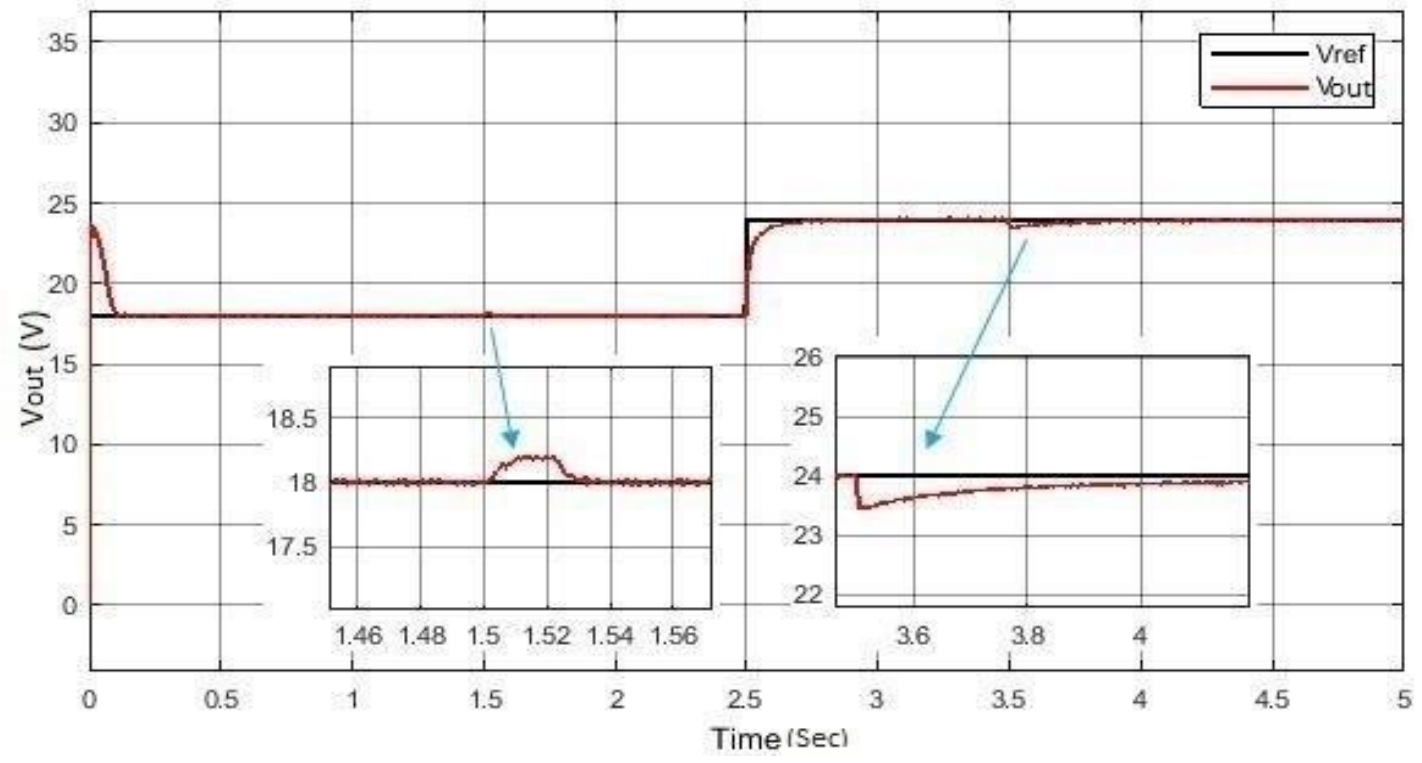

Figure 15. Graph obtained when output voltage increased from $18 \mathrm{~V}$ to $24 \mathrm{~V}$ 


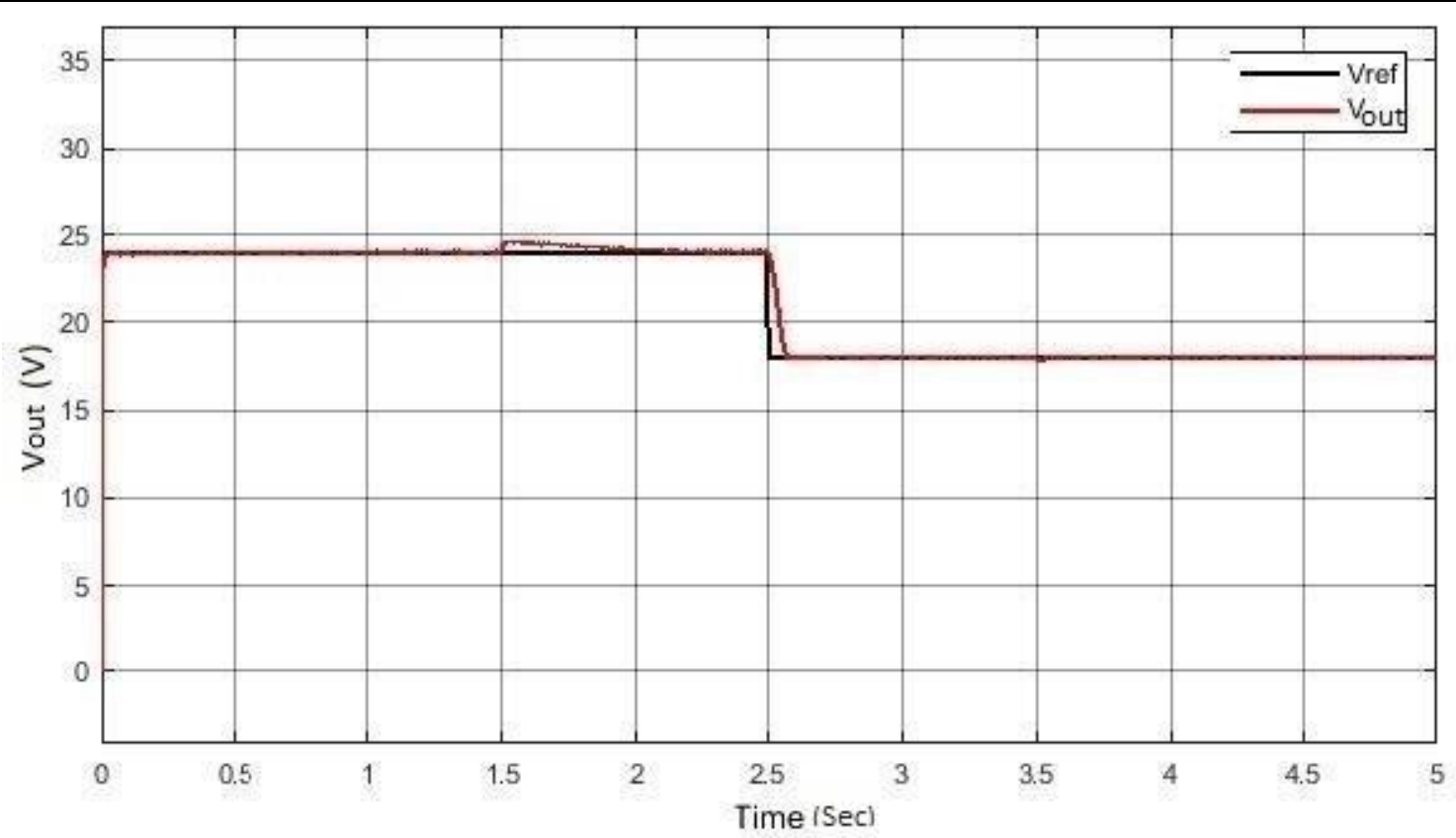

Figure 16. Graph obtained when output voltage drops from $24 \mathrm{~V}$ to $18 \mathrm{~V}$.

The converter output voltage value was increased from $18 \mathrm{~V}$ to $24 \mathrm{~V}$, while the load increased by $100 \%$ and system performance was examined. The results are shown in Figure 17.

When the system performance is examined when the load is increased by $100 \%$, it is seen that the desired output voltage values for both $18 \mathrm{~V}$ and $24 \mathrm{~V}$ are obtained from the converter output. It is observed that there is a small error during the change of the sun's radiation in the output voltage of $24 \mathrm{~V}$ but the desired voltage is obtained with the help of the PID controller. The converter for $18 \mathrm{~V}$ output voltage produced voltage in the range of $17.99-18.01 \mathrm{~V}, 24 \mathrm{~V}$ to 23.99 to $24.01 \mathrm{~V}$.

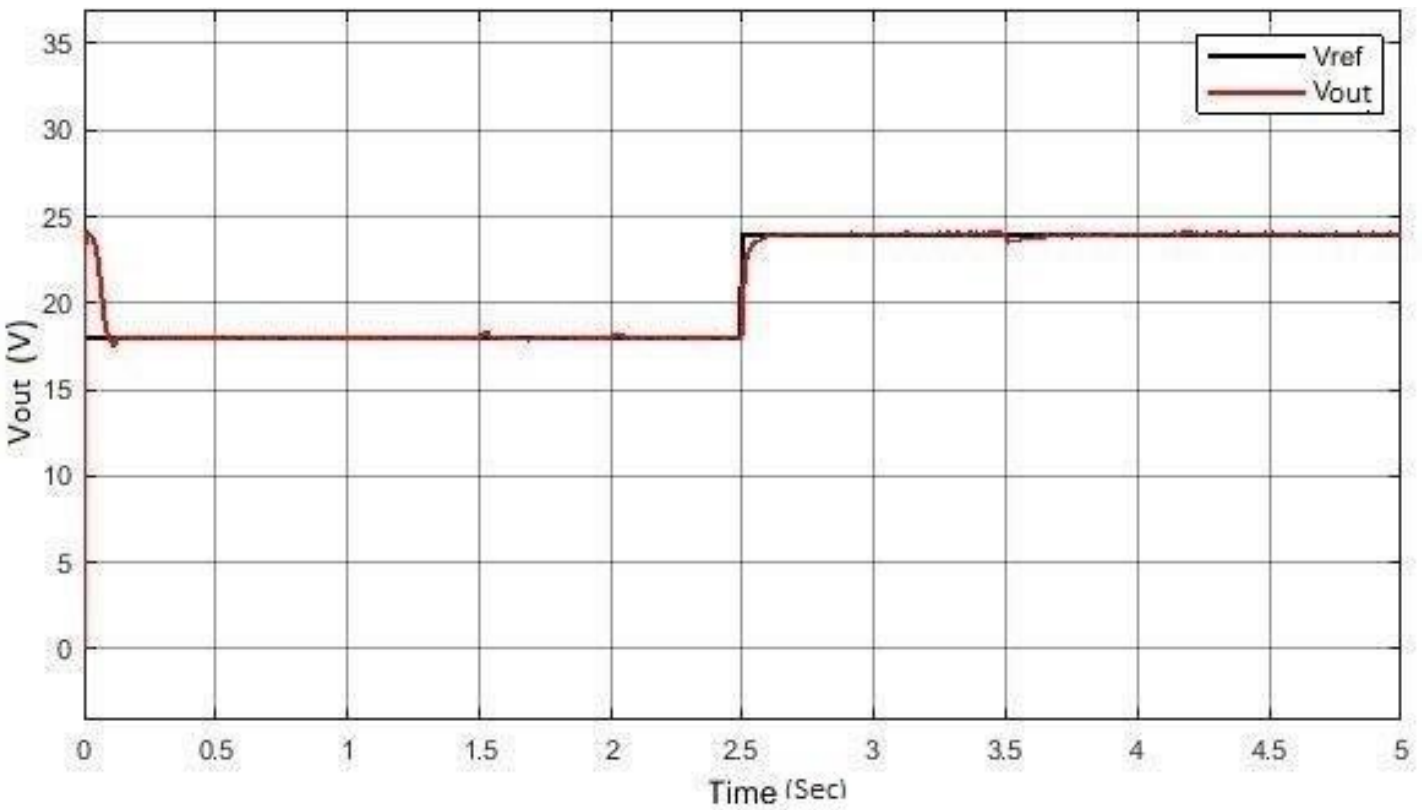

Figure 17. Results obtained when the load is increased by $100 \%$

The converter output voltage value was increased from $18 \mathrm{~V}$ to $24 \mathrm{~V}$ while the load was reduced by $50 \%$ and system performance was examined. The results are shown in Figure 18.

For the $18 \mathrm{~V}$ output voltage the converter produced voltage between $17.85-18.18 \mathrm{~V}, 24 \mathrm{~V}$ for $23.75-$
24.25 V. The chart below shows that when seconds show 3.5 , the sun's radiation drops from $500 \mathrm{w} / \mathrm{m}^{2}$ to $200 \mathrm{w} / \mathrm{m}^{2}$. From this moment on the PID converter is trying to keep the output voltage at the desired level. However, this situation deteriorated in the range of 4.5-5 seconds. 


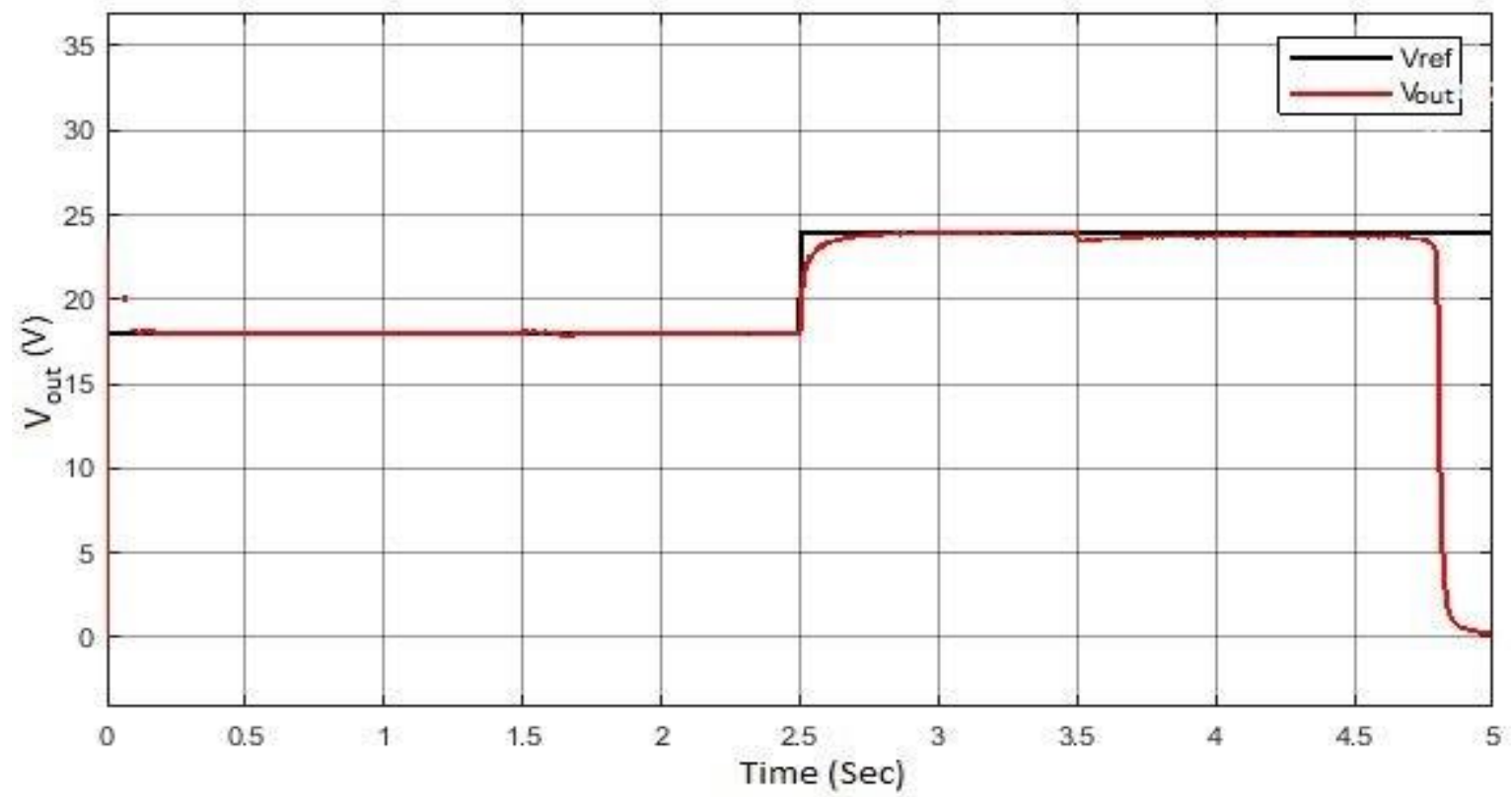

Figure 18. Results obtained when the load is reduced by $50 \%$.

\subsection{Comparative analysis results}

In the case of converter output 18 and $24 \mathrm{~V}$, comparative findings for both models are given in this section. Graphs:

\section{VOUT1 : Hard switching (Uninsulated) DC-DC boost}

converter output VOUT2 : Soft switching (Insulated) DC-DC boost

converter output VREF : Shows the desired voltage at the converter output.

The value of solar radiation in the system is as in referenced values. The load is fixed on the system.
The performance of both models for $18 \mathrm{~V}$ is shown in Figure 19. The red line(VOUT1) is more efficient than the blue line(VOUT2) because there were two breaks on the blue line. But this does not mean the second model (VOUT2) cannot be used. Only the first model (VOUT1) has a lower error rate. When Figure 19 is examined, it is seen that the hard switching converter for $18 \mathrm{~V}$ gives better answers to the change in solar radiation values with PID controller in the aforementioned PV system.

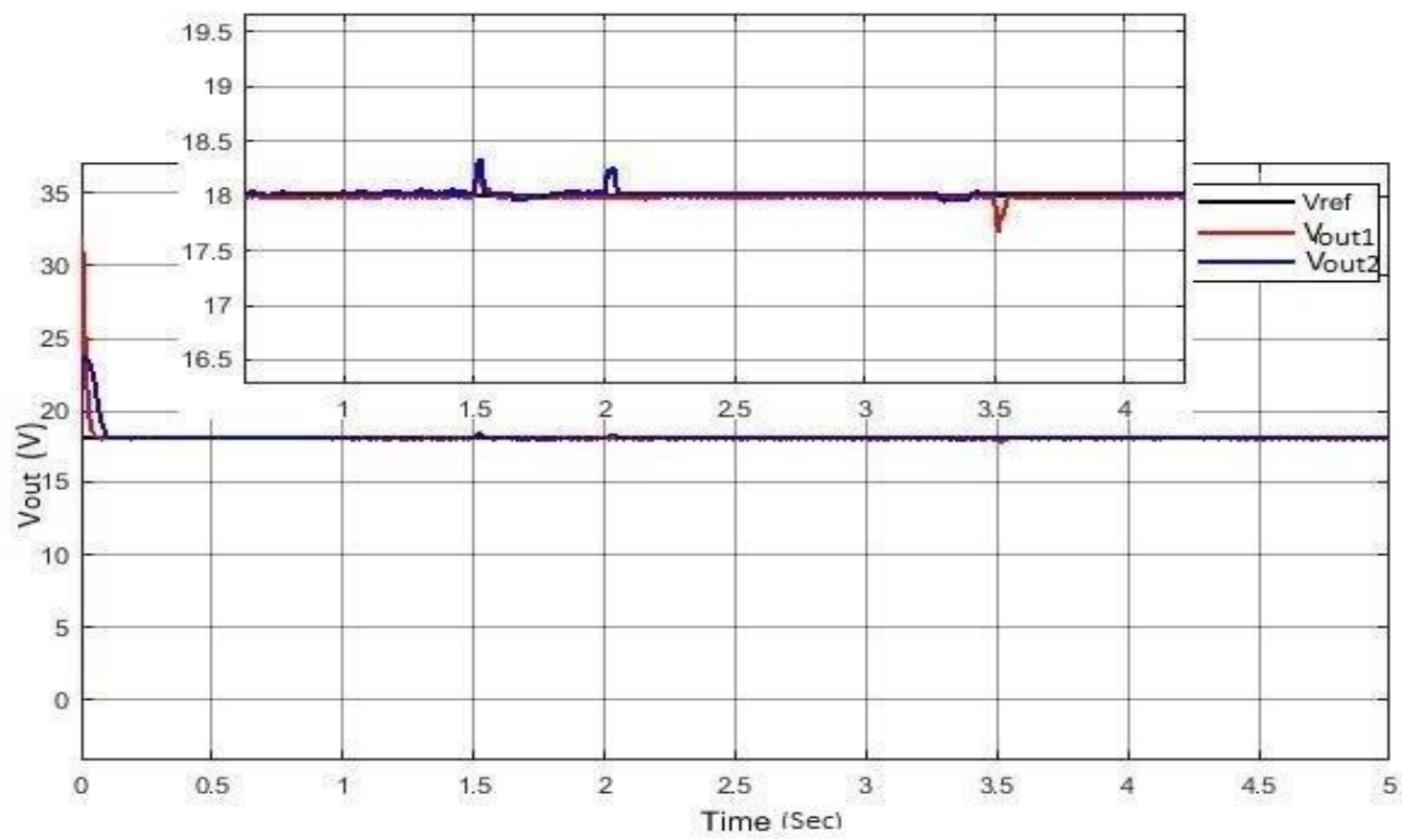

Figure 19. Comparative analysis findings for $18 \mathrm{~V}$. 
The performance of both models for $24 \mathrm{~V}$ is shown in Figure 20. Here again, there were breaks in both models, but the break of the blue line (Vout2) was a little too much. When figure 20 is examined, it is seen that the hard switching converter for $24 \mathrm{~V}$ gives better answers to the change in solar radiation values with PID controller in the aforementioned PV system.

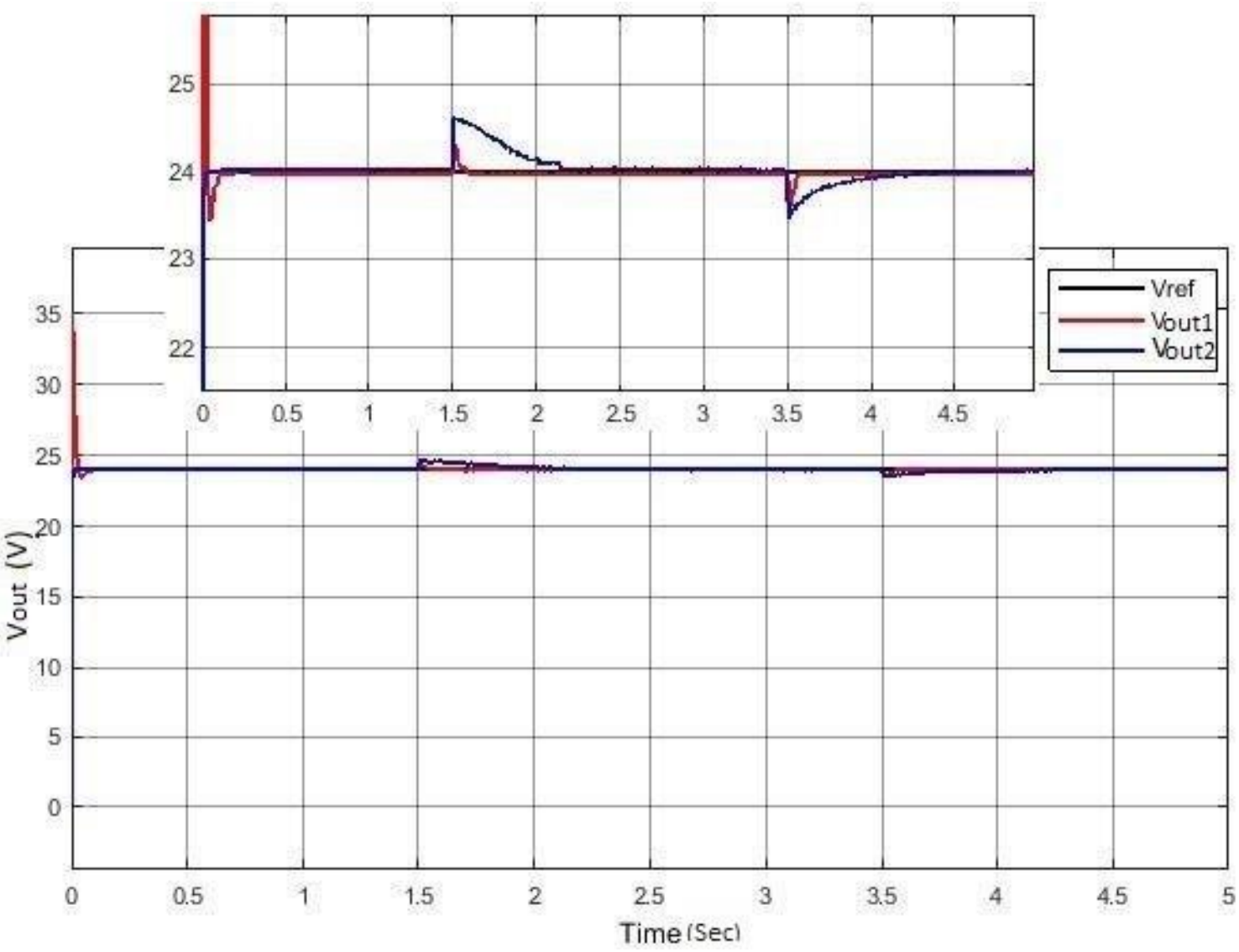

Figure 20. Comparative analysis findings for $24 \mathrm{~V}$.

\section{CONCLUSION}

In this study, the performance of DC-DC boost converters was investigated on a PV system and the desired voltages at the converter output were checked with PID controller and the evaluations of the system's performance were presented below:

- The PV system output produces 12-13 V voltage and this voltage is applied to the DCDC converter input. The output of the PV system varies according to the solar radiation value.

- It adjusts the PID controller switching function according to the voltage value obtained from the output of the PV system and ensures that the desired voltages are obtained from the converter output.

- $\quad$ HS and SS converters produced high stability levels for $18 \mathrm{~V}$. The output voltage error in the HS boost DC-DC converter was $\pm 0.12 \%$ and the SS boost was $\pm 0.28 \%$ in the DC- DC converter. In this case, the HS converter performed better.
- $\quad$ HS and SS converters produced high stability levels for $24 \mathrm{~V}$. The output voltage error in the HS boost DC-DC converter was $\pm 0.08 \%$ and the SS boost was $\pm 2.2 \%$ in the DC-DC converter. In this case, the HS converter performed better.

- If the load increased by $100 \%$, converters produced high stability levels when examined in Figure 11 (HS) and Figure 17 (SS). In detail, the HS boost DC-DC converter produced better results than any other.

- If the load is reduced by $50 \%$, the converters' stability levels are better at $18 \mathrm{~V}$ when examined in Figure 12 (HS) and Figure 18 (SS). The performance of the $24 \mathrm{~V}$ HS converter is better than the SS converter. But 4-5 for $24 \mathrm{~V}$ the converter output with SS between seconds has failed. This can be said to be due to the drop of the sun's radiation at halfload and high output voltage. 
In this context;

$>\quad$ On full load and $100 \%$ increased load, PID controlled HS boost converter can be said to produce better results and can be recommended for PV systems.

$>$ The best results on the semi-load are achieved at the output voltage value of $18 \mathrm{~V}$.

$>$ It is understood that the HS converter produced the best results in switching with the PID controller.

\section{ACKNOWLEDGMENT}

This study was funded by Istanbul University -

Cerrahpasa with the project number FYL-2019-33778.

\section{REFERENCES}

[1] Lakshmi, M., \& Hemamalini, S. (2019). Coordinated control of MPPT and voltage regulation using single- stage high gain DC-DC converter in a grid-connected PV system. Electric Power Systems Research, 169, 65-73.

[2] Sheng, K., Williams, B. W., \& Finney, S. J. (2000). A review of IGBT models. IEEE transactions on Power Electronics, 15(6), 12501266.

[3] Bodur, H., Aksoy, I., \& Akin, B. (2002). Soft switching techniques in DC-DC converters. Source Electric, 158, 100-108.

[4] Kazimierczuk, M. K. (2015). Pulse-width modulated DC-DC power converters. John Wiley $\&$ Sons.

[5] Hua, G., Yang, E. X., Jiang, Y., \& Lee, F. C. (1993, June). Novel zero-current-transition PWM converters. In Proceedings of IEEE Power
Electronics Specialist Conference-PESC'93 (pp. 538-544). IEEE.

[6] Hua, G., Leu, C., \& Fred, C. (1992). Lee,". Novel Zero-Voltage-Transition PWM Converters" IEEE PESC, 55-61.

[7] Bodur, H., \& Bakan, A. F. (2004). A new zvt-zctpwm dc-dc converter. IEEE transactions on power electronics, 19(3), 676-684.

[8] Das, P., \& Moschopoulos, G. (2007). A comparative study of zero-current-transition PWM converters. IEEE Transactions on Industrial Electronics, 54(3), 1319-1328.

[9] Kondawar, S. S., \& Vaidya, U. B. (2012). A Comparison of two MPPT techniques for PV system in Matlab/Simulink. International Journal of Engineering Research and Development, 2(7), 73-79.

[10] Moubayed, N., El-Ali, A., \& Outbib, R. (2009). A comparison of two MPPT techniques for PV system. WSEAS Transactions on Environment and Development, 5(12), 770-779.

[11] Arulselvi, S., Uma, G., \& Chidambaram, M. (2004, August). Design of PID controller for boost converter with RHS zero. In The 4th International Power Electronics and Motion Control Conference, 2004. IPEMC 2004. (Vol. 2, pp. 532-537). IEEE.

[12] Dave, M. R., \& Dave, K. C. (2012). Analysis of boost converter using PI control algorithms. International Journal of Engineering Trends and Technology, 3(2), 71-73.

[13] Amirahmadi, A., Rafiei, M., Tehrani, K., Griva, G., \& Batarseh, I. (2015). Optimum design of integer and fractional-order PID controllers for boost converter using SPEA look-up tables. Journal of Power Electronics, 15(1), 160-17 